\title{
Hepatits E presenting as acalculous cholecystitis
}

\author{
Stefania Chetcuti Zammit, Neville Azzopardi, Edgar Pullicino \\ Department of Gastroenterology, Mater Dei Hospital, MALTA
}

Correspondence: Stefania Chetcuti Zammit. Address: Department of Gastroenterology, Mater Dei Hospital, Msida MSD 2090, MALTA. Email: stf_che@yahoo.com

Received: December 09, 2014

Accepted: J une 11, 2015

Online Published: June 28, 2015

DOI : $10.5430 /$ crim.v2n3p30

URL: http://dx.doi.org/10.5430/crim.v2n3p30

\section{Abstract}

We report a case of a 30-year-old female who presented with right upper quadrant pain and jaundice 30 days after consuming uncooked food in Thailand. Ultrasound examination of the hepatobiliary system revealed a distended gallbladder, thickened wall, sludge and a positive Murphy's sign, suggesting acalculous cholecystitis. Hepatitis E IgM antibodies were positive. She was treated conservatively with $\mathrm{N}$-acetylcysteine, intravenous antibiotics and cholestyramine, pending the hepatitis E IgM result, with a gradual but full recovery. The association of acalculous cholecystitis with Hepatitis $\mathrm{E}$ is rarely described in the literature. Hepatitis E infection should be suspected in patients presenting with ultrasonographic changes in the gallbladder, in areas where hepatitis $\mathrm{E}$ is endemic or where there is a suggestive history.

\section{Keywords}

Acalculous cholecystitis, Hepatitis E, Gallbladder thickening, Jaundice

\section{I ntroduction}

There are very few reported cases of acalculous cholecystitis in association with hepatitis E. We describe a case of a female patient who presented with jaundice and gallbladder changes on ultrasound which were subsequently found to be secondary to viral hepatitis E infection.

\section{Case report}

A 30-year-old female presented to our hospital with a 5 day history of jaundice, epigastric and right upper quadrant pain with associated nausea, decreased appetite and severe itching. She denied loose bowel motions at the time. She had travelled to Pakistan and Thailand 2 months previously where she had eaten mangos and pineapples from a street stall.

Physical examination was unremarkable except for an icteric tinge and tenderness in the epigastrium and right upper quadrant. She was afebrile. She had significantly deranged liver function tests at presentation (see the Table). Ultrasound examination of the biliary system demonstrated a thickened, distended gallbladder wall with sludge in the lumen and a positive sonographic Murphy's sign (see the Figure). Hepatitis C antibodies and PCR, Adenovirus IgA, Leptospira serology, CMV serology and EBV PCR were all negative. Hepatitis A IgG was positive but Hepatitis A IgM was negative. 
Hepatitis B serology was negative except for Hepatitis B surface antibody consistent with previous hepatitis B vaccination. Hepatitis E IgM was found to be positive.

She was treated with intravenous hydration and ceftriaxone. In view of severe itching she was also started on cholestyramine. $\mathrm{N}$-acetylcysteine was commenced due to liver failure pending the hepatitis E serology results. Her liver function tests showed gradual improvement and the patient was discharged home eight days following her admission to hospital (see the Table).

Table. Blood results during the patient's hospital stay and after discharge home

\begin{tabular}{|c|c|c|c|c|c|c|c|c|c|}
\hline & Day 1 & Day 2 & Day 3 & Day 4 & Day 5 & Day 6 & Day 7 & Day 8 & $\begin{array}{c}\text { Day } 7 \text { after } \\
\text { discharge home }\end{array}$ \\
\hline $\begin{array}{l}\text { Alkaline Phosphatase } \\
(40-129 \mathrm{u} / \mathrm{l})\end{array}$ & 212 & 208 & 195 & 188 & 169 & 157 & 149 & 147 & 119 \\
\hline $\begin{array}{l}\text { Alanine Amino Transferase } \\
(1.0-41 \mathrm{u} / \mathrm{l})\end{array}$ & 1965 & 1602 & 1736 & 1226 & 860 & 671 & 392 & 302 & 157 \\
\hline $\begin{array}{l}\text { Gamma Glutamyl Transferase } \\
(11.0-50 \mathrm{u} / \mathrm{l})\end{array}$ & 110 & 100 & 94 & 88 & 76 & 70 & 59 & 57 & 48 \\
\hline $\begin{array}{l}\text { Bilirubin } \\
(\leq 22 \mu \mathrm{mol} / \mathrm{L})\end{array}$ & 163.50 & 182.10 & 164.50 & 170.00 & 136.90 & 120.5 & 98.60 & 82.60 & 53.4 \\
\hline Albumin $(35-50 \mathrm{~g} / \mathrm{L})$ & 32.1 & 36.3 & 35.5 & 33.5 & 33.1 & 32.8 & 37.5 & 39.5 & 39.0 \\
\hline $\begin{array}{l}\text { Platelets } \\
\left(150-450 \times 10^{9} / \mathrm{L}\right)\end{array}$ & 194 & 175 & 188 & 208 & 215 & 220 & 245 & 245 & 240 \\
\hline INR (0.8 to 1.2$)$ & 1.52 & 1.36 & 1.33 & 1.30 & 1.30 & 1.20 & 1.20 & 1.10 & 1.0 \\
\hline $\begin{array}{l}\text { White cell count } \\
\left(3.5-10.5 \times 10^{9} \mathrm{~L}\right)\end{array}$ & 6.90 & 7.70 & 6.4 & 6.8 & 5 & 4.6 & 5.3 & 4.6 & 5.5 \\
\hline $\operatorname{CRP}(<6)$ & 95 & 101 & 120 & 125 & 114 & 93 & 85 & 80 & 15 \\
\hline
\end{tabular}
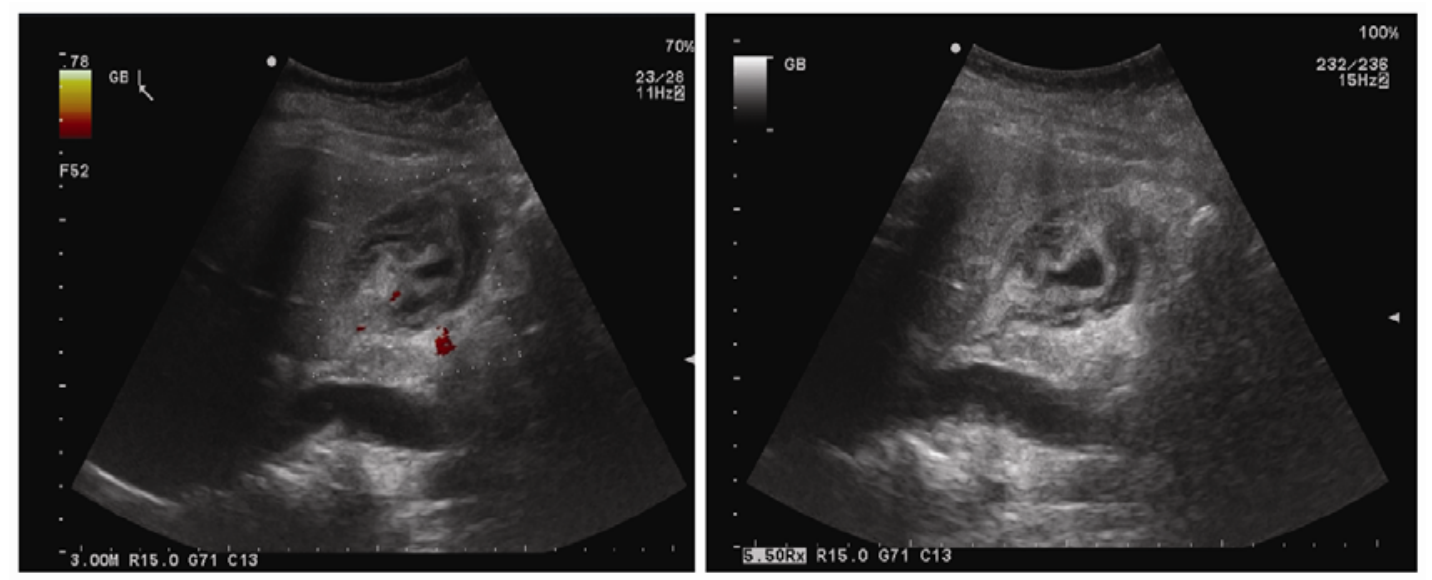

Figure. Ultrasound of the gallbladder showing a thickened gallbladder wall and sludge within the lumen

\section{Discussion}

We report the case of a patient with imported hepatitis E from a developing country. Hepatitis E infection can also be acquired through the consumption of uncooked or undercooked meat in industrialised countries. Public health data in 2014 in the UK demonstrated a $92.8 \%$ positive Hepatitis E plasma antibody rate in slaughtered pigs with $47 \%$ of these being IgM positive ${ }^{[1]}$. This underlines the importance of having a high index of suspicion for the infection in symptomatic patients presenting with typical features but who have no history of foreign travel. 
Gallbladder changes on ultrasound have been described in 50\%-100\% of adults with acute viral hepatitis. The commonest findings are gallbladder collapse and gallbladder wall thickening ${ }^{[2-7]}$ and are more frequently observed in patients with: hepatitis A infection, females, high bilirubin level ${ }^{[8]}$ and high liver enzymes ${ }^{[9,10]}$. Patients with structural gallbladder changes on ultrasound and acute hepatitis A infection have a poorer prognosis ${ }^{[1]]}$.

Acute acalculous cholecystitis can have a high complication rate and mortality if not treated early. Sensitivity and specificity of ultrasonography in diagnosing acute acalculous cholecystitis is reported to be up to $93 \%$ and $100 \%$ respectively ${ }^{[12-16]}$.

Most studies refer to 2 major or 1 major and 2 minor criteria that need to be satisfied for the diagnosis of acute acalculous cholecysititis. Major criteria include a thickened gallbladder wall of $3.5 \mathrm{~mm}$ or more, pericholecystic fluid or subserosal oedema, intramural gas and sloughed mucosal membrane. Minor criteria include echogenic bile (sludge) and hydrops ${ }^{\text {[17-26] }}$ Gallbladder wall thickness should not be used as the only feature that identifies cholecystitis as it can be a non-specific finding in other diseases such as heart failure and kidney disease ${ }^{[27]}$. Our patient was a healthy young female with no past medical history that could have explained the gallbladder findings.

Other features that are commonly observed in acute hepatitis infection on ultrasound imaging include accentuated brightness and more extensive demonstration of the portal vein walls and decreased echogenicity of the liver ${ }^{[28]}$. However increased brightness and clear visualization of portal vein radicle walls can also be found in healthy patients ${ }^{[29]}$.

Our patient did not satisfy the above criteria but had a thickened gallbladder wall with sludge in the lumen and a positive sonographic Murphy's sign in the absence of gallstones. These features point towards acute inflammation of the gall bladder. Murphy's sign can help distinguish acute acalculous cholecystitis from a distended gallbladder caused by prolonged fasting. However Murphy's sign may be masked by altered mental status or medications. A positive Murphy's sign has a sensitivity of $86 \%$ to $97 \%{ }^{[30-32]}$.

Our patient had very high alanine amino transferase and bilirubin levels, commonly found in patients with acute viral hepatitis. She also had hypoalbuminaemia and a raised INR consistent with liver failure. All of these started to improve eventually. Despite the acute infection, white cell count was normal. The CRP level was elevated. CRP is usually high in acute viral hepatitis, especially in hepatitis A infection ${ }^{[33]}$ and correlates well with deranged liver function tests ${ }^{[34]}$.

To our knowledge, the only case report in the literature of acalculous cholecystitis in hepatitis E was that of a child who developed hydrops of the gallbladder ${ }^{[2]}$. The incidence of acalculous cholecystitis in hepatitis $\mathrm{E}$ is reported to be between $76 \%$ to $85 \%$ in the current literature ${ }^{[35,36]}$.

Several mechanisms have been proposed to explain gallbladder wall thickening in patients with acute hepatitis. Hepatocyte necrosis is extensive in patients with acute hepatitis, causing an inflammatory reaction in the tissues surrounding the liver, including the gallbladder wall ${ }^{[37]}$. Viral hepatitis leads to increased activation of the factor XII-coagulation pathway causing damage to the blood vessels supplying the gallbladder, resulting in ischaemia ${ }^{[38]}$. The hepatitis virus in bile juice can cause direct injury to the muscular layers of the gallbladder ${ }^{[39]}$, as well as lymphatic obstruction. However, the condition most likely results from an increase in bile viscosity, due to prolonged stasis, that eventually leads to an obstruction of the cystic duct ${ }^{[40]}$.

Treatment of acalculous cholecystitis in association with viral hepatitis is initially conservative with intravenous hydration. Early cholecystectomy should be carried out if complications such as perforation, gangrene or abscess are suspected $^{[41]}$. Antibiotics might play a role in acalculous cholecysitis as initially the diagnosis of viral hepatitis might not be evident, as in our case. Antibiotics might also have a role in the early management of complications or possibly prevent secondary bacterial infection. Our patient was managed conservatively with intravenous fluids, antibiotics and $\mathrm{N}$-acetylcysteine due to the severely deranged liver function tests pending the diagnosis of Hepatitis E. 
Viral hepatitis should be highly suspected in those patients with acute signs of cholecystitis, absence of gallstones on ultrasound and deranged liver function tests. Early recognition is important due to the potential lethal complications that can result if this infection is undetected.

\section{Conclusion}

Hepatitis E infection should be highly suspected in patients with evidence of acalculous cholecystitis on ultrasound who present with typical signs and symptoms, especially if they have a recent travel history to areas with a high incidence of hepatitis E infection.

\section{Acknowledgements}

The authors would like to thank Dr Christine Azzopardi from the Radiology Department (Mater Dei Hospital, Malta) for providing and interpreting ultrasound images.

\section{References}

[1] Tedder R. Hepatitis E Virus infection in UK pigs at the time of slaughter.

UCL on behalf of Blood Borne Virus Unit Virus Reference Dept Public Health England, 2013.

http://webarchive.nationalarchives.gov.uk/20140707135733/http://www.defra.gov.uk/ahvla-en/files/pig-survey-hepatitisE-results .pdf.

[2] Sinha R, Negi V, Sawhney MPS, et al. A Rare Association of Hydrops of Gallbladder with Hepatitis E Infection. J Nep Paedtr Soc. $2011 ; 31: 216-222-223$.

[3] Maresca G, De Gaetano AM, Mirk P, et al. Sonographic patterns of the gallbladder in acute viral hepatitis. J Clin Ultrasound. 1984; 12(3): 141-6. PMid:6423687 http://dx.doi.org/10.1002/jcu.1870120305

[4] Sharma MP, Dasarathy S. Gallbladder abnormalities in acute viral hepatitis: a prospective ultrasound evaluation. J Clin Gastroenterol. 1991; 13(6): 697-700. http://dx.doi.org/10.1097/00004836-199112000-00018

[5] Giorgio A, Francica G, Amoroso P, et al. Morphologic and motility changes of the gallbladder in response to acute liver injury. A prospective real-time sonographic study in 255 patients with acute viral hepatitis. J Ultrasound Med. 1989; 8(9): 499-506. PMid:2674472

[6] Portincasa P, Moschetta A, Di Ciaula A, et al. Changes of gallbladder and gastric dynamics in patientsmwith acute hepatitis. Eur J Clin Invest. 2001; 31(7): 617-22. PMid:11454017 http://dx.doi.org/10.1046/j.1365-2362.2001.00834.x

[7] Zivković R, Trajer A. Ultrasound diagnosis of acute viral hepatitis. Acta Med Croatica. 1998; 52(2): 109-13. PMid:9682498

[8] Suk KT, Kim CH, Baik SK, et al. Gallbladder wall thickening in patients with acute hepatitis. J Clin Ultrasound. 2009; 37(3): 144-8. PMid:19035335 http://dx.doi.org/10.1002/jcu.20542

[9] Kim MY, Baik SK, Choi YJ, et al. Endoscopic sonographic evaluation of the thickened gallbladder wall in patients with acute hepatitis. J Clin Ultrasound. 2003; 31(5): 245-9. PMid:12767019 http://dx.doi.org/10.1002/jcu.10167

[10] Maudgal DP, Wansbrough-Jones MH, Joseph AE. Gallbladder abnormalities in acute infectious hepatitis. A prospective study. Dig Dis Sci. 1984; 29(3): 257-60. PMid:6697864 http://dx.doi.org/10.1007/BF01296260

[11] Ahn JH, Chung JJ, Yu JS, et al. Prognostic value of gallbladder wall thickening in patients with acute hepatitis A. Ultrasonography. 2015; 34(2): 139-43. PMid:25672770 http://dx.doi.org/10.14366/usg.14052

[12] Mirvis SE, Vainright JR, Nelson AW, et al. The diagnosis of acute acalculous cholecystitis: a comparison of sonography, scintigraphy, and CT. AJR Am J Roentgenol. 1986; 147(6): 1171-5. PMid:3535451 http://dx.doi.org/10.2214/ajr.147.6.1171

[13] Zeman AK, Burrell Ml, Cahou CF, et al. Cholescintigraphy, ultrasound, and computerized tomography in the evaluation of biliary tract disorders. Semin NucI Med. 1979; 9: 22-35. http://dx.doi.org/10.1016/S0001-2998(79)80005-7

[14] Ralls PW, Colletti PM, Halls JM, et al. Diagnostic utility of cholescintigraphy and ultrasound in acute cholecystitis. Am J Surg. 1981; 141: 446-451. http://dx.doi.org/10.1016/0002-9610(81)90138-0

[15] Ralls PW, Colletti PM, Halls JM, et al. Prospective evaluation of 99m Tc-IDA cholescintigraphy and grey-scale ultrasonography in the diagnosis of acute cholecystitis. Radiology. 1982; 144: 369-371 18.

[16] Deitch EA, Engel JM. Acute acalculous cholecystitis. Am J Surg. 1981; 142(2): 290-2.

http://dx.doi.org/10.1016/0002-9610(81)90295-6 
[17] Barie PS, Eachempati SR. Acute acalculous cholecystitis. Curr Gastroenterol Rep. 2003; 5: 302-309. PMid:12864960 http://dx.doi.org/10.1007/s11894-003-0067-x

[18] Beckman I, Dash N, Sefczek RJ, et al. Ultrasonographic findings in acute acalculous cholecystitis. Gastrointest Radiol. 1985; 10: 387-389. PMid:3902551 http://dx.doi.org/10.1007/BF01893137

[19] Mariat G, Mahul P, Prev TN, et al. Contribution of ultrasonography and cholescintigraphy to the diagnosis of acute acalculous cholecystitis in intensive care unit patients. Intensive Care Med. 2000; 26: 1658-1663. PMid:11193273 http://dx.doi.org/10.1007/s001340000684

[20] Deitch EA, Engel JM. Ultrasonic detection of acute cholecystitis with pericholecystic abscesses. Am Surg. 1981; 47: $211-214$. PMid:7015938

[21] Shuman WP, Rogers JV, Rudd TG, et al. Low sensitivity of sonography and cholescintigraphy in acalculous cholecystitis. AJR Am J Roentgenol. 1984; 142: 531-534. PMid:6607639 http://dx.doi.org/10.2214/ajr.142.3.531

[22] Mirvis SE, Vainright JR, Nelson AW, et al. The diagnosis of acute acalculous cholecystitis: a comparison of sonography, scintigraphy, and CT. AJR Am J Roentgenol. 1986; 147: 1171-1175. PMid:3535451 http://dx.doi.org/10.2214/ajr.147.6.1171

[23] Boland GWL, Slater G, Lu DSK, et al. Prevalence and significance of gallbladder abnormalities seen on sonography in intensive care unit patients. AJR Am J Roentgenol. 2000; 174: 973-977. PMid:10749232 http://dx.doi.org/10.2214/ajr.174.4.1740973

[24] Deitch EJM. Ultrasound in elective biliary tract surgery. Am J Surg. 1980; 140: 277-283. http://dx.doi.org/10.1016/0002-9610(80)90022-7

[25] Molenat F, Boussuges A, Valantin V, et al. Gallbladder abnormalities in medical ICU patients: an ultrasonographic study. Intensive Care Med. 1996; 22: 356-358. PMid:8708175 http://dx.doi.org/10.1007/BF01700459

[26] Imhof M, Raunest J, Ohmann C, et al. Acute acalculous cholecystitis complicating trauma: a prospective sonographic study. World J Surg. 1992; 16(6): 1160-1165. PMid:1455890 http://dx.doi.org/10.1007/BF02067089

[27] Shlaer WJ, Leopold GR, Scheible FW. Sonography of the thickened gallbladder wall: a nonspecific finding. AJR Am J Roentgenol. 1981; 136(2): 337-9. PMid:6781256 http://dx.doi.org/10.2214/ajr.136.2.337

[28] Kurtz AB, Rubin CS, Cooper HS, et al. Ultrasound findings in hepatitis. Radiology. 1980; 136(3): 717-23. PMid:7403553 http://dx.doi.org/10.1148/radiology.136.3.7403553

[29] Giorgio A, Amoroso P, Fico P, et al. Ultrasound evaluation of uncomplicated and complicated acute viral hepatitis. J Clin Ultrasound. 1986; 14: 675-679. PMid:3098787 http://dx.doi.org/10.1002/jcu.1870140903

[30] Ralls PW, Colletti PM, Lapin SA, et al. Real-time sonography in suspected acute cholecystitis. Prospective evaluation of primary and secondary signs. Radiology. 1985; 155(3): 767-71. PMid:3890007 http://dx.doi.org/10.1148/radiology.155.3.3890007

[31] Bree RL. Further observations on the usefulness of the sonographic Murphy sign in the evaluation of suspected acute cholecystitis. J Clin Ultrasound. 1995; 23(3):169-172. PMid:7730462 http://dx.doi.org/10.1002/jcu.1870230304

[32] Singer AJ1, McCracken G, Henry MC, et al. Correlation among clinical, laboratory, and hepatobiliary scanning finding in patients with suspected acute cholecystitis. Ann of Emerg Med. 1996; 28: 267-272. http://dx.doi.org/10.1016/S0196-0644(96)70024-0

[33] Atono Y1, Sata M, Tanikawa K. Kinetics of C-reactive protein in acute viral hepatitis. Gastroenterol Jpn. 1989; $24(6)$ : 655-62. PMid:2514117

[34] Amer Taha T. Evaluation of C- Reactive Protein (CRP) Titer in Patients with Acute Hepatitis A Virus Infection. Journal of al-qadisiyah for pure science (quarterly). 2011; 16(1): 1-10.

[35] Ibrahim AS, Alkhal A, Jacob J, et al. Hepatitis E in Qatar imported by expatriate workers from Nepal: epidemiological characteristics and clinical manifestations. J Med Virol. 2009; 81: 1047-51. PMid:19382273 http://dx.doi.org/10.1002/jmv.21474

[36] Sudhamsu KC. Ultrasound findings in acute viral hepatitis. Kathmandu Univ Med J (KUMJ). 2006; 4(4): 415-8.

[37] Juttner HU, Ralls PW, Quinn MF, et al. Thickening of the gallbladder wall in acute hepatitis: ultrasound demonstration. Radiology. 1982; 142: 465. PMid:7054838 http://dx.doi.org/10.1148/radiology.142.2.7054838

[38] Glenn F, Becker CG. Acute acalculous cholecystitis. An increasing entity. Ann Surg. 1982; 195: 131-136. PMid:7055388 http://dx.doi.org/10.1097/00000658-198202000-00002

[39] Dogra R, Singh J, Sharma MP. Enterically transmitted non-A, non-B hepatitis mimicking acute cholecystitis. Am J Gastroenterol. 1995; 90: 764. PMid:7733085

[40] Dupriest AW, Khaveja SC, Cowley AA. Acute cholecystitis complicating trauma. Ann Surg. 1979; 89(1): 84-89. http://dx.doi.org/10.1097/00000658-197901000-00016

[41] Kaya S, Eskazan AE, Ay N, et al. Acute Acalculous Cholecystitis due to Viral Hepatitis A. Case Rep Infect Dis. 2013. PMid:24106622 http://dx.doi.org/10.1155/2013/407182 